\title{
Lumen
}

Selected Proceedings from the Canadian Society for Eighteenth-Century Studies

\section{Oppositional Christian Symbolism and Salvation in Blake's America: A Prophecy}

\section{Catherine M. André}

Volume 37, 2018

URI : https://id.erudit.org/iderudit/1042231ar

DOI : https://doi.org/10.7202/1042231ar

Aller au sommaire du numéro

Éditeur(s)

Canadian Society for Eighteenth-Century Studies / Société canadienne d'étude du dix-huitième siècle

ISSN

1209-3696 (imprimé)

1927-8284 (numérique)

Découvrir la revue

Citer cet article

André, C. M. (2018). Oppositional Christian Symbolism and Salvation in Blake's America: A Prophecy. Lumen, 37, 199-213. https://doi.org/10.7202/1042231ar 


\title{
Oppositional Christian Symbolism and Salvation in Blake's America: A Prophecy
}

\author{
Catherine M. André \\ Queen's University
}

William Blake's America: A Prophecy illustrates the ineffectiveness of a nation's reliance on oppositional codes to define the care of its citizens. The rigid nature of dichotomies, such as those embedded within The Book of Isaiah and The Book of Revelation, prevents necessary national change in times of socio-political oppression. America demonstrates that if the rigidity of religious binaries influences the philosophy and behaviour of lawmakers and statesmen they will not achieve the national development to which they aspire. As laid out in America, the oppositional nature and non-interactive state of Christian binaries renders them static and non-progressive to human development. America takes these binaries and transforms them into what Blake calls "contraries," which embody a multiplicity of states that exist in fluid interaction to neutralize Biblical imagery (into a state of neither "good" nor "evil") and to promote a regenerative socio-political system. For example, in the "Preludium" to America, the daughter of Urthona says to Orc: "thy fire and my frost / Mingle in howling pains, in furrows by thy lightnings rent." The energy, or "lightning," of Orc breaks the firm distinction between fire and frost. This scenario's blurring together of binaries through rebellious energy transforms them into contraries that do not exist in opposition but in a state of necessary tension. This transformation of binaries is equally apparent in the

1. William Blake, America: A Prophecy, in The Complete Poetry and Prose of William Blake, ed. David V. Erdman (New York: Anchor Books, 1988), 52. 
Angel's transformation into a devil in Marriage of Heaven and Hell. ${ }^{2}$ There is no distinction between angel and devil but there is rather a fluid bridge between the two. Blake outlines his philosophy of contraries in "The Argument:"

Without Contraries is no progression. Attraction and Repulsion, Reason and Energy, Love and Hate, are necessary to Human existence. From these contraries spring what the religious call Good \& Evil. Good is the passive that obeys Reason[.] Evil is the Active springing from Energy. Good is Heaven. Evil is Hell. ${ }^{3}$

Heaven as a representation of good and hell as that of evil are binaries created by the "religious" that render these people passive and inactive. According to Blakean philosophy, Christian binaries are dangerous if they are not approached as contraries in constant flux and co-existence. The speaker places these dual concepts in tandem with one another to demonstrate a relationship that is necessary for a person's development and, on a larger scale, for a nation's energetic "progression."

In orthodox Christian belief, binaries often represent God's act to distinguish between those, on the one hand, who are obedient to his law and worthy of his salvation and, on the other, those who refuse to obey and conform. Examples of these symbolic binaries are the biblical story of the gentle sheep defending themselves against the lion or the viper that threatens God's faithful. It is known from Christopher Rowland's Blake and the Bible and Leslie Tannenbaum's Biblical Tradition in Blake's Early Prophecies that the King James version of The Book of Revelation and The Book of Isaiah are central to many of Blake's works. ${ }^{4}$ Both Isaiah and Revelation symbolize those who are disobedient to the laws of God within forms deemed opposite to the divine; these people are unworthy rebels not suited for salvation. There is an observable relationship between biblical Christian binaries and Blakean contraries within America.

Blake's America represents a revolutionary force in the form of the creature "Orc." What the current field says about Orc's role in America

2. William Blake, The Marriage of Heaven and Hell, in The Complete Poetry and Prose of William Blake, ed. David V. Erdman (New York: Anchor Books, 1988), 44.

3. Ibid., 34 .

4. Christopher Rowland, Blake and the Bible (New Haven: Yale University Press, 2010); Leslie Tannenbaum, Biblical Tradition in Blake's Early Prophecies: The Great Code of Art (Princeton: Princeton University Press, 1982), 133. 
is various. Blake scholars David Erdman and Mark Schorer interpret Orc as a character of positive change through revolution, while other scholars view Orc's rebellion as representative of futility. ${ }^{5}$ Northrop Frye's argument that Orc is an ambiguous creature that continually undergoes a seven-stage cycle of development is well known and, at times, contested by scholars such as Erdman and Christopher Hobson. ${ }^{6}$ Frye argues that Orc is the "power of rejuvenation" who undergoes a very human cycle of birth, death, and rebirth throughout Blake's poetry to represent the "American cultural cycle." For this reason, Frye believes that Orc is not a hero figure in America but that revolution and regeneration themselves are the heroes of Blake's poems. ${ }^{8}$ Hobson, on the other hand, argues that Orc "represents not a cyclic upsurge but the energy that is bound with the repression of sexuality and the creation of oppressed populations and classes" such as in "historical revolutions." Hobson states that Orc instead is a "multivalent symbol of oppression and opposition" and argues for the ambiguity in Orc's character. ${ }^{10}$ Leslie Tannenbaum expands on Orc's ambiguity, asserting: "Blake portray[s] the American Revolution as a battle of contraries." Instead of defining Orc by a cycle of birth, death, and rebirth, scholars like Hobson and Tannenbaum value the contrary nature of Orc. He is a complex creature who stands contrary to pattern and logic. Rather than following a clear linear or cyclical pattern, Orc is both birth and death; he closes the gap in the circle and forces contrary states into simultaneous existence and conversation with one another. Tannenbaum believes that America's dual representation of Orc as regenerative and destructive in energy presents him as "a demonic Messiah," or a Christ and anti-Christ in one. ${ }^{12}$ It is through this duality in his character that Orc comes to embody ambiguous

5. The viewpoints of David Erdman, Mark Schorer, and various "other scholars," on Orc are outlined in Christopher Z. Hobson, The Chained Boy: Orc and Blake's Idea of Revolution (Plainsboro: Associated University Presses, 1999), 19.

6. Frye's argument on Orc (and Erdman and Hobson's alternate arguments) is outlined in Hobson, Chained Boy, 18-19, 46-53.

7. Frye qtd. in Hobson, Chained Boy, 218, 228.

8. Northrop Frye, Fearful Symmetry: A Study of William Blake (Princeton: Princeton University Press, 1947), 251.

9. Hobson, Chained Boy, 53.

10. Ibid., 47 .

11. Tannenbaum, Biblical Tradition, 133.

12. Ibid., 134 . 
meaning and America questions the traditional system of biblical Christian binaries with respect to nationhood and its development. ${ }^{13}$ This paper adds to these critical discussions the argument that it is Orc's ambiguity in America that converts static Christian binaries into a system of interactive contraries, a transformation that is necessary to produce Orc's regenerative energy for the sake of America's development.

Blake's integration of certain oppositional Christian symbolism into scenes of Orc's rebellious energy demonstrates the ineffectiveness of a sole reliance on binaries to foster necessary socio-political change. The potential of binaries for regeneration only occurs when Orc converts Christian binaries into Blakean interactive contraries. America specifically represents Orc as an embodiment of both the contrary qualities described in Isaiah and Revelation: the serpent and God, the First Beast and God, the unrighteous victim and the divine wielder of the plagues, and as unholy creature of a hot and cold nature. America challenges and subverts conceptualizations of nationhood and citizenry that are founded in traditional dichotomous symbolism. The revolutionary power of their reconstruction into interactive contraries by Orc suggests that disobedience of rigid religious and state law can be redemptive and even divine. This paper argues that Orc's energy dissolves Christian biblical binaries in America and effectively aligns Orc with both the lawbreakers and God from The Book of Isaiah and The Book of Revelation to demonstrate the synonymy of Orc's rebellious energy with divinity and the necessity of this contrary state to escape the socio-political oppression of stagnant dichotomies.

America's representation of Orc's energy as lawbreaker intermingles the biblical oppositional imagery of serpent and God until they become contraries. Orc appears in the form of the biblical serpent as he threatens to destroy dichotomous law: "I am Orc, wreath'd round the accursed tree ... That stony law I stamp to dust: and scatter religion abroad / To the four winds as a torn book, \& none shall gather the leaves." ${ }^{4}$ The image of Orc as a serpent "wreath'd round the accursed tree" alludes to the biblical image of the disobedient serpent. Orc enacts its traditional role as he stamps "stony laws to dust" and tears apart binary-infested religious texts. Orc's form suggests the "Eternal

13. Ibid., 135 .

14. Blake, America, 54 . 
Viper self-renew'd,"15 which Revelation defines as "the old serpent, which is the Devil, and Satan," the opposing enemy of God..$^{16}$ Traditional biblical representations of "the viper" in The Book of Isaiah define it as a symbol of "a rebellious people, lying children, children that will not hear the law of the LORD" and thus are rendered "a people that shall not profit" from salvation. ${ }^{17}$ It is the biblical viper's rebellious and disobedient nature of "the law of the Lord" that makes it worthless and unfit to "be called holy."18 America's representation of Orc as a rebellious serpent plays into this traditional biblical image of a disobedient creature that acts contrary to God's law and remains unfit for salvation but transforms it with descriptions of salvation like those promised by God in Isaiah.

Orc claims that the torn book and the "stony law" shall "rot on desart sands, \& consume in bottomless deeps; / To make the desarts blossom, \& the deeps shrink to their fountains, / And to renew the fiery joy, and burst the stony roof." ${ }^{19}$ A nation's established laws and religious doctrine hold little salvific potential because their static nature destroys the "fiery joy" of the American peoples and "[perverts] to ten commands" each person's internal energy. ${ }^{20}$ It is the opening of binaries to interact as contraries in national philosophy that can offer renewal to America. Orc's energetic act to break established laws and to "burst the stony roof" of temples "make[s] the desarts blossom" and fountains emerge. This scene of Orc's disobedient assertion of energy expands the symbol of the biblical serpent to equally encompass the image of Isaiah's salvific God. The Book of Isaiah describes God's promise of a renewed land to the Israelites as such: "Israel shall blossom and bud, and fill the face of the world with fruit" because "[God] give $[s]$ waters in the wilderness, and rivers in the desert, to give drink to [his] people, [his] chosen." ${ }^{21}$ The sign of the fulfillment of God's salvation in Isaiah is the "blossom and bud" of the desert and the nourishing rivers for his "chosen" faithful people. The fact that Orc's

15. Ibid.

16. The Book of Revelation 20:2 (King James Version. Subsequent references are to this version, unless otherwise noted).

17. The Book of Isaiah 30:6, 30:9.

18. Isaiah $4: 3$

19. Blake, America, 54 .

2o. Ibid.

21. Isaiah $27: 6,43: 20$. 
serpentine rebellion recreates God's promise "[t]o make the desarts blossom, \& the deeps shrink to their fountains" demonstrates Orc's fluidity between the orthodox symbols of serpent and God, which suggests the divine impulse of Orc's rebellious energies. ${ }^{22}$

Christopher Rowland states that Blake is "part of a long tradition of ambivalence about assent to a written code and the preference for the indwelling Spirit as a source of theological insight" and "divine impulse." 23 The "indwelling Spirit" is a creature's internal energy that is itself divine; while the external "assent to a written code," in which lie these oppressive binaries, holds little to no salvific potential. Since Orc's name itself is a disorder of the "written code" for "rock," he simultaneously holds the sanctifying energy of the God of Isaiah (often called "the Rock") in addition to the disobedient serpent. ${ }^{24}$ Orc's embodiment of disorder through his very namesake is what makes him alike to the sanctity of God. Orc's destruction of the city stones therefore transforms the God and serpent binary into an interactive contrary state. Indeed, Orc claims that those who incite disorder and disobedience like him are holy, because "every thing that lives is holy, life delights in life; / Because the soul of sweet delight can never be defil'd." ${ }^{25}$ Every creature that lives with his/her own energy to "delight in life" traverses into the realm of the holy. Salvific energy is not reserved to the biblical God and his saints alone. Any creature that possesses his/her own "soul of sweet delight," or internal energy and desires, "can never be defiled." Even in serpentine form and rebellion, they simultaneously align with the divine energy and forms of God. Rowland explains, "being indwelt by, or being in some other way identified with the divine, means that there is no need for any external directive of behaviour, because how one lives is according to the divine impulse." ${ }^{26}$ Any creature that lives by his/her internal energy can be "identified with the divine" and its "divine impulse," and thus they have no need for the "external directives" of rigid "stony law" and "ten commands." ${ }^{27}$ Orc's defiance of external structures and law cannot be

\footnotetext{
22. Blake, America, 54 .

23. Rowland, Blake and the Bible, 200, 204.

24. Isaiah 26:4 (New American Version), (Wichita: Saint Jerome Press, 1991).

25. Blake, America, 54 .

26. Rowland, Blake and the Bible, 204.

27. Blake, America, 54 .
} 
an act of "evil" because his behaviour stems from his internal directive. The fact Orc acts with internal energy suggests the holiness of his choice to break rigid laws and tear apart religious texts.

Orc also appears in a larger form than that of the biblical serpent. Orc's emergence from the Atlantic sea not only echoes the First Beast's rise in Revelation but also the salvific energy of God. Orc rises as "a Wonder o'er the Atlantic sea" to end the Americans' submission to the stringent rule of statesmen and politicians. ${ }^{28}$ Similarly, the First Beast of Revelation "rise[s] up out of the sea" to persecute the obstinate followers of the biblical God: "[the First Beast] opened his mouth in blasphemy against God, to blaspheme his name, and his tabernacle." ${ }^{29}$ As Austin Farrer states, the First Beast is a "symbolical . . . figure of the Antichrist," and it is the "greatest enemy of God and of his saints." ${ }^{30}$ The image of Orc's rise from the sea in conjunction with the Antichrist figure of the First Beast supports Orc's role as rebellious "Anti-England" who rises contrary to an inflexible state.

The description of rising Orc challenges the effectiveness of relying on binary codes to fuel revolutions by equating Orc's rebellious energy with its contrary, the God of Isaiah. The following image of God signifies the coming divine salvation for the people of Israel: "the name of the LORD cometh from far, burning with his anger, and the burden thereof is heavy: his lips are full of indignation, and his tongue as a devouring fire ... to sift the nations with the sieve." ${ }^{11}$ God approaches his people with the intention of "devouring" and destroying the unrighteous nations. Anger and indignation are the predominant energies that accompany this image of the God of salvation. Though not always common in the Bible, in this case it appears that the God of Isaiah demonstrates his divine intervention for the sake of his holy people through a contrary state of hellish forms of fire and low-burning clouds. America represents Orc as also appearing from fiery, energetic clouds when he rises from the sea: "Red rose the clouds from the Atlantic in vast wheels of blood / And in the red clouds rose a Wonder

28. Ibid., 53 .

29. Rev. 13:1, 13:6.

30. Austin Farrer, The Revelation of St. John The Divine: Commentary on the English Text, (Oxford: Oxford University Press, 1964), 151-2.

31. Isaiah. 30:27-8. 
o'er the Atlantic sea." 32 The emergence of Orc out of the fiery "red clouds" with the intention of destruction through his "vast wheels of blood" mirrors the approach of the God of Isaiah to the salvation of his oppressed people. Like Isaiah's representation of God's divine intervention, Orc's form embodies contrary states. He is a creature of red fiery energy that oozes blood and death while he approaches America as a grand, energetic creature of hope and "Wonder." 33 The similitude of Orc with the God of Isaiah demonstrates Orc's embodiment of salvific energy through his bloody fires and destruction. Hence, Orc is God-like as he rises as the demonic First Beast. The energetic intermingling of these contrary forms of God and First Beast occurs in the following scene in America: "the Demon red, who [burns] towards America, / In black smoke thunders and loud winds rejoicing in its terror / Breaking in smoky wreaths from the wild deep." 34 Orc approaches America, just as "the Lord cometh from far," in dark smoke and shifting winds that burn with the wrath of God-like energy as well as with the "Demon red" synonymous with the First Beast from the "wild deep." 35 This rebellious energy is so great in its salvation that it is a terror in which the King of England trembles and Orc rejoices for its salvation of the oppressed. ${ }^{36}$

The description in America of Orc's self-release from captivity also merges the image of Revelation's First Beast with the God of salvation. Orc's confinement to an abyss, in which "[r]ivets [are his] tenfold chains while still on high [his] spirit soars," suggests the biblical abyss or the "bottomless pit" in which the Beast temporarily is sealed so that "he should deceive the nations no more." ${ }^{37}$ Traditionally only an agent of God with "the key of the bottomless pit" can release the beast and those who worship its image. ${ }^{38}$ However, Orc himself has internal energy that still soars high, which enables him to "rend the links, free" of his own volition. ${ }^{39}$ Orc releases himself from the abyss without the aid of the necessary angel and rises from the sea in the image of the

\footnotetext{
32. Blake, America, 53.

33. Ibid., 53.

34. Ibid., $55-56$.

35. Isaiah. 30:27-8; Blake, America, 55 .

36. Blake, America, 53, 55.

37. Ibid., 51; Rev. 20:3.

38. Rev. 20:1, 20:4.

39. Blake, America, 52.
} 
defiant First Beast. ${ }^{40}$ Even upon release, the Beast of Revelation traditionally remains under the control of God: "it was given unto [the First Beast] to make war with the saints, and to overcome them: and power was given him [by God] over all kindreds, and tongues, and nations." ${ }^{\text {1 }}$ God gives the Beast his power to wage war against those considered to be holy; the First Beast's revolt against the saints and their nations is an act of God. The description of Orc as First Beast, both with internal energy for self-release from the abyss and defiance of dichotomous doctrine, aligns his acts of rebellion with the orders of God. In this way, Orc's disobedience is a form of obedience, a Blakean contrary state that demonstrates the divine energy at play within Orc's rebellion. The interaction of the biblical binaries of First Beast and God illustrates what Rowland describes as the reconciliation of the "disjunction between human activity and divine activity . . . because God indwells men and women who are capable through the imaginative and creative work." ${ }^{2}$ Orc's disobedient act of self-release from the abyss, arguably an "imaginative and creative" act in its nonconformity, demonstrates his connection to the "indwelling" God. Orc's "human activity" of self-release is a "divine activity;" his act as disobedient Beast is simultaneously an act of God.

America's dual representation of Orc as the wielder and intended victim of the plagues from Revelation reinforces the salvific nature of Orc's revolt. The hosts of Albion's Angel in America gather "[a]rm'd with diseases of the earth to cast upon the Abyss" out of which Orc emerges. ${ }^{43}$ In Revelation, the biblical plagues that pour from God's wrath obey only him to infect the disobedient: "there fell a noisome and grievous sore upon the men which had the mark of the beast, and upon them which worshipped his image." ${ }^{44}$ As just retribution, God's plagues infect only those who obey the demonic Beast and his ways. The plagues honour God's instruction by protecting the righteous while harming the oppressors. Similarly, in America the plagues of Albion's Angel are supposed to be "obedient to his voice" to infect the rebellious spirit of Orc, but they backfire on him and his followers

40. Ibid., 53.

41. Rev. 13:7.

42. Rowland, Blake and the Bible, 121.

43. Blake, America, 56.

44. Rev. 16:2. 
while Orc remains immune to them. ${ }^{45}$ The fact that the plagues backfire to infect both the limbs of Albion's Guardian and the main sites of state law, Bristol and London, with such "grievous sores" illustrates that immutable laws and their enforcers, not Orc, are the ones who are harmful and hold "the mark of the beast." ${ }^{\text {"6 }}$ At the sight of Orc's immunity to the plagues, the priests recognize their susceptibility and "[r] ush into reptile coverts, hiding from the fires of Orc." ${ }^{\text {"47 }}$ The cowering of the priests from both the plagues and Orc's fires attributes "the mark of the beast" to them; their invariable doctrines punish and afflict the American people. Other law-bearers hide from Orc in caves: the "punishing Demons terrified / Crouch howling before their caverns deep." ${ }^{\prime 4}$ America's state rulers, whom Albion's Angel himself calls "punishing Demons," crouch terrified of Orc's initial rebellion against their plagues of dichotomous law. ${ }^{49}$ The representation of people cowering in caves in America mirrors those who hide from the salvation of the Lord in Revelation: "The kings of the earth, and the great men, and the rich men, and the chief captains, and the mighty men ... hid themselves in the dens and in the rocks of the mountains ... from the wrath of the Lamb." ${ }^{50}$ It is the city rulers, the rich, and the powerful who cannot withstand God's wrathful and redemptive energy. The cowering of state and religious law-enforcers in caves and dens from the energy of Orc demonstrates the God-like salvation of Orc's wrath. Indeed, biblically it is only a God-like energy that can shelter and protect people from such phenomena as plagues: "for upon all the glory [of God] shall be a defense." ${ }^{51}$ Orc's rebellious energy's potential to offer immunity and defense, both to himself and to the American people, from plagues of socio-political oppression glorifies his disobedience as divine.

America describes Orc as not only immune to the plagues but also as having divine control over them. As the plagues contact Orc, his "red fires rag'd! the plagues recoil'd! then rolld they back with fury /

45. Blake, America, 56 .

46. Ibid., 56-57; Rev. 16.2).

47. Blake, America, 57.

48. Ibid., 54 .

49. Ibid.

50. Rev. 6:15-17.

51. Isaiah 4:6. 
On Albions Angels." ${ }^{2}$ It is Orc's raging energetic "red fires" that prompt the plagues to backfire onto Albion's Angel and his followers, again marking them as the unyielding oppressors. Orc's energy additionally draws the plagues towards himself and places them under his control: "The plagues creep on the burning winds driven by flames of Orc, / And by the fierce Americans rushing together in the night." ${ }^{\text {. } 33}$ The representation of Orc's energetic "burning winds" and flames taking control of the plagues, specifically their ability to "drive" the plagues, reinforces that it is Orc's dynamic energy as law-breaker that aligns his rebellion with the divine energies of God's wrath. ${ }^{54}$ The concept of God's wrath in Revelation is an ambiguous one, one that embodies both Christian notions of good (God) and evil (wrath) in one dynamic energy. It is peculiar that in Isaiah's representation of shelter and defense, as outlined above, the source of glory is also left ambiguous, the same ambiguity in salvation that Orc himself embodies through Blakean contraries. It is the contrary divine disobedience of Orc's ambiguity that is necessary to grant the American peoples with enough fierce energy to band together in the night and revolutionize America.

Orc also creates tension between the hot and cold binary outlined in Isaiah and Revelation. The mixture of hot and cold energy when Orc releases himself from his chains in the abyss indicates that his act of defiance unifies his energy with that of divine salvation. The voice of Christ in Revelation establishes the traditional separation of these binaries in scripture: "I know thy works, that thou art neither cold nor hot: I would thou wert cold or hot. So then because thou art lukewarm, and neither cold nor hot, I will spue thee out of my mouth." ${ }^{55}$ An act that is solely hot or cold is necessary for a creature to earn salvation from God; if they are a mixture of the two they will be discarded as unholy. Traditionally, the intermingling of two binary states, represented by the term "lukewarm," suggests the "complacency [that] leads to the loss of fervor" and a "half-heartedness, or lack of zeal" to obey the Lord. ${ }^{56}$ For this reason, a person who is both hot and cold does not

52. Blake, America, 56.

53. Ibid., 57 .

54. Rev. 16:1-2.

55. Ibid. 3:15-16.

56. Farrer, Revelation of St. John, 83, 82. 
conform to the narrow law of God but follows it nonchalantly. Within the context of these biblical allusions, Orc's choice to mingle his fires with the daughter of Urthona's frost, creating a lukewarm sensation, marks Orc as lazy, complacent, and ultimately unfit for God's salvation. ${ }^{57}$ Contrary to this hot and cold imagery in Revelation, when Orc's fires mix with frost it releases him from prison and grants him with the energy he needs to instigate revolution in the American state.

Orc's appearance as simultaneously rebel and "the image of God" throughout America reinforces this point. ${ }^{58}$ Orc first appears in God's image when he becomes a divine figure "fall'n to give [Urthona's daughter] life in regions of dark death." ${ }^{59}$ Life-giving energy accompanies Orc's experience of "struggling afflictions" between the fire of new life and the "howling pains" of Urthona's daughter's icy "eternal death." ${ }^{60}$ It is the contrary dynamism of hot and cold that offers Orc and Urthona's daughter life and energy; it does not place them into a state of sloth and useless complacency as Revelation claims. In this specific case, when binaries interact to form Blakean contraries "in some kind of dialectical relationship, [they] achieve spiritual maturity and any kind of change, political included." ${ }^{11}$ The dialectical relationship Orc creates between hot and cold offers him "spiritual maturity" and access to holy energy. The tension between contraries is what mark the "spiritual maturity" or the complete divinity of Orc's rebellious energy. It is only through contraries that a divine energy matures in Orc with the potential to incite political change for the salvation of the American peoples. Tannenbaum's argument that Blakean texts illustrate a "God [that] acts and is existing in human beings" reinforces Orc's salvific energy in this case. ${ }^{62}$ The eternal energy of the biblical God acts through and exists within Orc because of the humanness of Orc's physicality and emotions. Orc's own energy possesses a divine quality whose "existence is a sign, an indication of the eternal penetrating the temporal." 63 The imagery of the tension between hot and cold

\footnotetext{
57. Blake, America, 52.

58. Ibid.

59. Ibid.

6o. Ibid.

61. Rowland, Blake and the Bible, 85 .

62. Tannenbaum, Biblical Tradition, 74.

63. Ibid.
} 
sensations upon Orc's encounter with Urthona's daughter and the immense power in Orc's self-release demonstrates an eternal energy that must be acting through Orc's temporal being.

When Orc destroys rigid laws and the fires of his rebellion erupt in America, he asserts that a creature that acts through his/her own energy protects themselves from these fires: "Fires inwrap the earthly globe, yet man is not consumd; / Amidst the lustful fires he walks: his feet become like brass, / his knees and thighs like silver, \& his breast and head like gold." ${ }^{64}$ When humans exert their own energies and desires and then have to walk "amidst the lustful fires" of their own making, they will not be consumed by that energy. ${ }^{65}$ This representation stands in contrast with the traditional biblical representation of God's fire, a static energy that is all-consuming: "The light of Israel shall be for a fire, / and his Holy One for a flame, and it shall burn and devour ... And shall consume the glory of . . both soul and body." 66 The fire and flame of God's energy "burns and devours" both the human body and the spiritual energy of all those within it, whereas Orc's rebellious energy produces fires that are both hot in desire and cool so as not to consume entirely. Indeed, Orc's fire appears to be more salvific than God's flames in Isaiah through its contrary elements, since his "[f]ires inwrap the earthly globe, yet man is not consumd." ${ }^{67}$ America's representation of Orc's defiant non-consuming flames transforms the traditional image of God's all-consuming fire into one of national transformation and salvation.

It is only from Orc's fires of mingling hot and cold that the image of the man with brass feet emerges, which mirrors the representation of the Christ of salvation in Revelation: "his eyes were as a flame of fire; And his feet like unto fine brass, as if they burned in a furnace." 68 The flames of Christ in Revelation signify his fires of judgment "of which he [alone] is the master." ${ }^{\prime 9}$ The fact that Orc passes through his own fires unscathed proves his mastery of them and, thus, his divinity as the Christ-like wielder of the flames. However, in this case, it is the

\footnotetext{
64. Blake, America, 54 .

65 . Ibid.

66. Isaiah 10:17.

67. Blake, America, 54 .

68. Ibid.; Rev. 1:14-15.

69. Farrer, Revelation of St. John, 67.
} 
Blakean contrary state of Orc's frosty fires that grant him Christ-like power, not the burning "flame of fire" of Christ. America's representation of Orc's "lukewarm" fires of energy as comparable to those of Christ through the symbol of the brass feet demonstrates the divinity of Orc's rebellious energy. Farrer explains that the vestment of Christ in Revelation represents not "the Man of Nazareth transfigured, but [is] the Divine Glory personified." ${ }^{70}$ The fact Orc appears out of fires with the same feet of brass suggests his embodiment of "the Divine Glory personified." "7l However, the way in which America compares the vestments of Orc to the Christ of Revelation suggests that Orc's act of salvation transcends that of an unyielding God.

The fact that Orc appears in his non-consuming flames with not only feet of brass but his "knees and thighs like silver, $\&$ his breast and head like gold" suggests the transcendence of Orc's rebellious energy beyond that of Christ's divinity in Revelation. ${ }^{72}$ If Orc's fires have enough energy to craft silver and gold, rather than the simpler brass, then he must possess more powerful energy than Christ. ${ }^{73}$ Orc's defiant "lustful fires" hold more salvific energy than the "flame of fire" of Christ. ${ }^{74}$ Orc's adornment with gold on his head echoes the "helmet of salvation upon [the son of Jacob's] head" in Isaiah, which suggests that Orc's bearing the helmet represents a similar offer of salvation to the American people and their future generations. ${ }^{75}$ Since the refinement of gold is a more exquisite process than that of brass, as an "assay of fire refines the metal," Orc's emergence from his fires bearing a gold helmet, in addition to Christ's brass feet, reinforces the greater salvation Orc offers America through his revolt. ${ }^{76}$

America's representation of Orc in the contrary states of serpent and God, the First Beast and God, the unrighteous victim and God-like wielder of the plagues, and his mastery of hot and cold flames demonstrate that the dynamic tension of rebel and divine contraries instigates the revolutionary energy necessary for national change. The fact that

70. Rev. 1:14-15; Farrer, Revelation of St. John, 66.

71. Farrer, Revelation of St. John, 66.

72. Blake, America, 54 .

73. Farrer, Revelation of St. John, 68.

74. Blake, America, 54; Rev. 1:14.

75. Blake, America, 54 .

76. Isaiah 59:17; Farrer, Revelation of St. John, 68, 67. 
Orc's rebellious energy is synonymous with the divinity of the God of Isaiah and Revelation throughout America demonstrates the necessity of contrary states to erase the rigid dichotomies that incite sociopolitical oppression. What Orc's energy ultimately demonstrates is the power acquired through the tension of contraries may mark an individual as nonconformist rebel, but such marks are necessary to invoke social change. There are points in history when such rebellion was, and still is, required to better the lives of a stagnant or oppressed nation, to offer its people an ever-changing and hopeful future for generations to come. 